\title{
Transatlantica
}

Revue d'études américaines. American Studies Journal

\section{From Lafayette to Barack Obama: Past and Future in a Quilt Exhibit}

Patricia A. Turner

\section{(2) OpenEdition}

1 Journals

\section{Édition électronique}

URL : https://journals.openedition.org/transatlantica/4324

DOI : $10.4000 /$ transatlantica.4324

ISSN : 1765-2766

Éditeur

Association française d'Etudes Américaines (AFEA)

\section{Référence électronique}

Patricia A. Turner, «From Lafayette to Barack Obama: Past and Future in a Quilt Exhibit », Transatlantica [En ligne], 1 | 2009, mis en ligne le 02 septembre 2009, consulté le 19 septembre 2021. URL : http://journals.openedition.org/transatlantica/4324 ; DOI : https://doi.org/10.4000/ transatlantica.4324

Ce document a été généré automatiquement le 19 septembre 2021.

\section{c) () (위}

Transatlantica - Revue d'études américaines est mise à disposition selon les termes de la licence Creative Commons Attribution - Pas d'Utilisation Commerciale - Pas de Modification 4.0 International. 


\title{
From Lafayette to Barack Obama: Past and Future in a Quilt Exhibit
}

\author{
Patricia A. Turner
}

1 From January 7-21 $1^{\text {st }}$ of 2009, the City Hall of the Paris $5^{\text {th }}$ arrondissement was the venue for the "A Patchwork of Cultures: A Traveling Exhibit from Louisiana to France" quilt exhibit currently making its way through several major cities in France (Mulhouse, Lille, Marseille, Toulouse). The eye-opening exhibit was the brainchild of cultural Affairs Officer Lora Berg and Cultural Affairs Specialist Sophie Nadeau. While working in Louisiana, Nadeau was enthralled by a quilt exhibit commemorating the relationship between Lafayette, Louisiana and France. Eager to share the quilts, some made by Louisiana quilters and some made by Acadian quilters in Canada, with the French public, Berg and Nadeau solicited additional quilts that would make for an even broader exhibit, one that would also offer the aesthetic viewpoint of African-American quilt artists. The plan for an eighteen-month long traveling exhibit of quilts was an ambitious one so the Cultural Affairs office partnered with the City of Lafayette (Louisiana), French quilt scholar Géraldine Chouard, American quilt expert Diane de Obaldia (from Le Rouvray quilt shop and gallery) and the France-Louisiane and FrancePatchwork Associations.

2 Visitors to the exhibit during the January $7-21^{\text {st }}$ show were exposed to an even more extensive installation of quilts. Thanks to the support of the U. S. Embassy, several quilts crafted by Riché Richardson augmented the core Louisiana-oriented exhibit in the gallery. Richardson is the subject of a documentary made by Géraldine chouard and Anne Crémieux. ${ }^{1}$ Better known for her work as a literary scholar, Richardson herself was in Paris for several days of lectures and presentations; many visitors to City Hall that week were able to meet the artist herself. ${ }^{2}$

3 This essay evaluates the exhibit as it was mounted in city hall during those weeks in January. If we expect exhibitions to be teaching tools as well as delights to the eye, the "Patchwork of Cultures" exhibit had the potential to inform and inspire viewers about multiple themes. These include 1) the obvious attachment and gratitude residents of Lafayette feel for their French connections 2) the overall history and culture of quilting 
as an art form 3) the ways in which African-American Louisianans use quilts as expressive vehicles and, because of the corner of the gallery devoted to Riché Richardson's quilts, 4) the way one quilt artist articulates her history and values in her quilts.

\section{France and the New World}

$4 \quad$ Exhibit visitors were greeted by a colorful quilt with a smiling personified fleur-de-lys at its center made by textile artist Dahnell Bell. Naming her quilt "Walk the Walk Fleurde-lys" Bell used multiple primary colors of fabric to make its petals into the striped garb of a harlequin. A fitting welcome totem, the jaunty fleur-de-lys is just one of many visible symbols connecting the nation of France with the city of Lafayette and the state of Louisiana. Hanging adjacent to the quilt were the shiny plastic beads ubiquitous during Louisiana's annual Mardi Gras festival. Red, white and blue, these strands evoked both the flags of the United States, Acadian Canada, and France. These and other symbols, symbols of friendship, family, and all manner of culture were evident throughout the exhibit.

5 The fleur-de-lys motif repeats in several more of the quilts. And indeed several of the quilters and quilt guilds interpreted the celebration of the relationship between France and Louisiana very literally. Several quilts incorporate American flags, sailing ships, American eagles, musical notes, mariner's compasses, and images of George Washington into their designs. One particularly intricate quilt offers a fabric map of Poitiers, sister city to Lafayette and one of the regions from which some ancestors of Cajun, Louisiana and Acadia descent can be traced.

\section{Quilts as an Art Form}

6 In addition to the quilts themselves, the organizers of the exhibit used the space to inform patrons of the history and culture of quilts and quilters. The curators displayed a glass case and window shelf to a sample of the many books, journals, and magazines that have been devoted to quilt making. Concise informative essays (written by chouard) were placed at key spots throughout the exhibit space, and illustrated brochures were made available to visitors. Knowledgeable docents, many of them volunteers very familiar with quilting, were on hand to answer the questions of patrons to whom quilting was a new art form.

7 The quilts themselves reflected the scope of kinds of quilts made by contemporary quilt artists. Some such were samplers, a quilt that contains multiple different blocks such as "A Tribute To The Marquis de La Fayette," containing forty different blocks and "Tribute to La Fayette", a nine-patch sampler; others such as "Lafayette Orange Peel" show visitors the vitality that can be accomplished with a repeated block pattern. There were also medallion quilts including a much more formal and elegant white fleur-de-lys, titled "Believe", which offered a nice contrast to "Walk the Walk Fleur-delys." Overall, the curators were successful in providing an exhibit that succeeded for novice quilt exhibit attendees as well as those with extensive knowledge of the quilt world. 


\section{African-American Louisianans}

8 According to Kyra Hicks, one of the preeminent authorities of black quilt making, there are at least 1.9 million African-American quilters. ${ }^{3}$ " A Patchwork of Cultures » offers a balanced glimpse into the range of quilts made by African-Americans, and these quilts were interspersed between the quilts made to celebrate the Lafayette connections. One quilt contains the image of revolutionary war heroine Phyllis Wheatley, one of the first known black poets. By far the quilt that attracted the most attention during the exhibit was made by a survivor of the notorious Hurricane Katrina. In "Bad News Quilt and the Shroud of Katrina" Beatriz "Socco" Ocampo takes fabric and newsprint that itself survived the ravages of the hurricane and transforms items most other people would have discarded into a quilt with a design evocative of a crucifix. As the guest book to the exhibit attests, visitors to the exhibit frequently reported that this was the most moving quilt of the many displayed. Balancing the more nostalgic quilts elsewhere in the exhibit, "Bad News Quilt and the Shroud of Katrina" stands as a visceral reminder of the power of art.

\section{Riché Richardson}

During the same weeks "A Patchwork of Cultures" was in Paris, an exhibit of quilts was also on display in Washington D.C. Devoted to the newly elected President, Barack Obama, the Historical Society of Washington D.C. was home to an impressive array of quilts made to commemorate the new President of the United States. But Parisians did not have to go to the United States to see a Barack Obama quilt. While Riché Richardson was in Paris, her portrait quilt of the 44th president was on display in City Hall. Richardson specializes in quilts that are portraits of individuals important to her. Some are members of her family, others are political figures. Born and raised in Montgomery, Alabama, Richardson has always been fascinated by the intersections between many African-American artists and literary figures and French culture. ${ }^{4}$ She has marked this interest with quilts devoted to Josephine Baker and Simone de Beauvoir.

By putting several of her portrait quilts in one nook in the exhibit space, the curators of the exhibit offered their patrons the opportunity to see a range of quilts made by one artist. More so than in the diverse offerings in the core exhibit, the selection of quilts by Richardson, nicely anchored by information on her evolution as a quilt artist, provided viewers with an opportunity to see how one individual artist finds and enacts inspiration.

11 On Wednesday, January 14, 2009, a selection of Richardson's quilts were featured at a soiree celebrating the exhibit hosted by U.S. Ambassador Craig Stapleton at his elegant residence. Well over one hundred and fifty invitees were able to view the Chouard/ Crémieux documentary and ask questions of both the filmmakers as well as Richardson herself. Several of her colorful quilts, including the vibrant Josephine Baker, complete with a three-dimensional banana skirt and a smiling Simone de Beauvoir, decked out with real beads, jazzed up the classically decorated entertaining rooms of the residence.

Overall, "A Patchwork of Cultures: A Traveling Exhibit from Louisiana to France" stands as a very successful exhibit. As the curators planned to pack the exhibit up for its next 
stop, on January 20, the day of the inauguration of Barack Obama, a reminder of the quilters behind the exhibit was evident in Paris daily where a picture of Richardson and her Obama quilt was used to signal the change welcomed by so many in the international community. "A Patchwork of Cultures" proved that quilt artists connect us with the past, the present, and the future.

\section{NOTES}

1. Anne Crémieux and Géraldine Chouard, Portrait of the Artist: Riché Deianne Richardson. From Montgomery to Paris (Excuzemyfrench Productions, 2008).

2. Riché Richardson, Black Masculinity and the U.S. South: From Uncle Tom to Gangsta (University of Georgia Press, 2007).

3. Black Threads, http://www.blackthreads.blogspot.com/ October 14, 2007.

4. For more about Richardson see, Patricia A. Turner, Crafted Lives: Stories and Studies of AfricanAmerican Quilters (University of Mississippi Press, 2009) 75-84.

INDEX

Thèmes : Trans'Arts

\section{AUTEUR}

\section{PATRICIA A. TURNER}

The University of California, DavisPh.D, Author of Crafted Lives: Stories and Studies of AfricanAmerican Quilters 